\title{
An investigation on the effects of emotional intelligence in development of brand equity
}

\author{
Hosseinali Aziziha $^{\mathrm{a}}$, Ashkan Faraji ${ }^{\mathrm{a}}$, Ali Khodsetan ${ }^{\mathrm{b}}$, Reza Tahermanesh $^{\mathrm{a}}$, Seyed Shahab Mousavi ${ }^{\mathrm{a}^{*}}$ and \\ Elham Agha Alikhani ${ }^{\mathrm{a}}$
}

${ }^{a}$ Department of Management and Accounting, South Branch, Islamic Azad University, Tehran, Iran

${ }^{b}$ Department of Management and Accounting, Allameh Tabatabaee University, Tehran, Iran

\section{H R O N I C L E}

\begin{tabular}{l}
\hline Article history: \\
Received June 28, 2013 \\
Received in revised format \\
19 October 2013 \\
Accepted 20 December 2013 \\
Available online \\
December 222013 \\
\hline Keywords: \\
Brand equity \\
Emotional intelligence \\
Telecommunication industry
\end{tabular}

\section{A B S T R A C T}

This paper presents an investigation on the effects of various components of emotional intelligence including self-awareness, emotional management, sympathy, social skills and selfmotivation on building brand equity in telecommunication industry. The proposed study of this paper uses two questionnaires, one for measuring emotional intelligence and the other for measuring brand equity. The study was performed among 384 people who had used telecommunication industry services in city of Tehran, Iran. Using Spearman correlation test, as well as structural equation modeling, the study has confirmed the positive effects of four emotional components, including self-awareness, emotional management, social skills and selfmotivation influence on building brand equity in telecommunication industry.

\section{Introduction}

Having a good brand plays essential role for the success of most organizations and there have been tremendous efforts to detect important factors influencing brand equity such as emotional intelligence (Aaker \& Joachimsthaler, 2003; Callarisa et al., 2012). Brands must be managed as valuable and long-term corporate assets and the relationship between brand loyalty and brand value has to be recognized within the management accounting system. We also need to keep in our mind that strategic brand management is accomplished by having a multi-disciplinary concentration, which is facilitated by a common vocabulary. Wood (2000) tried to build the relationships between the constructs and concepts of branding, and to present a framework and vocabulary that helps effective communication between the functions of accounting and marketing. King and Grace (2010) presented the first known empirically-tested framework of Employee Based Brand Equity (EBBE) by looking into how organizations not only effectively manage the internal brand building-process but also appreciate the subsequent employee effects and organizational benefits. 
Biedenbach et al. (2011) examined whether factors associated with customers' perception of employees' behavior in terms of customer perceived role ambiguity, role overload and customeremployee rapport impact the development of brand equity in the professional service context. The results of the implementation of structural equation modeling in their survey indicated negative impacts of role ambiguity and role overload on brand associations, perceived quality and brand loyalty, which constitute brand equity. The findings indicated a positive impact of customeremployee rapport on the enhancement of business to business brand equity. However, the negative impacts of role ambiguity and role overload on customer-employee rapport transfer detrimental indirect impacts on brand equity. Veasna et al. (2013) investigated the effect of destination source credibility on destination satisfaction by looking into some evidences on the mediating impacts of destination attachment and destination image.

\section{The proposed study}

This paper presents an investigation on the effects of various components of emotional intelligence including self-awareness, emotional management, sympathy, social skills and self- motivation on building brand equity in telecommunication industry. All questions of the survey were designed in Likert scale from one to five. Fig. 1 demonstrates the structure of the proposed study.

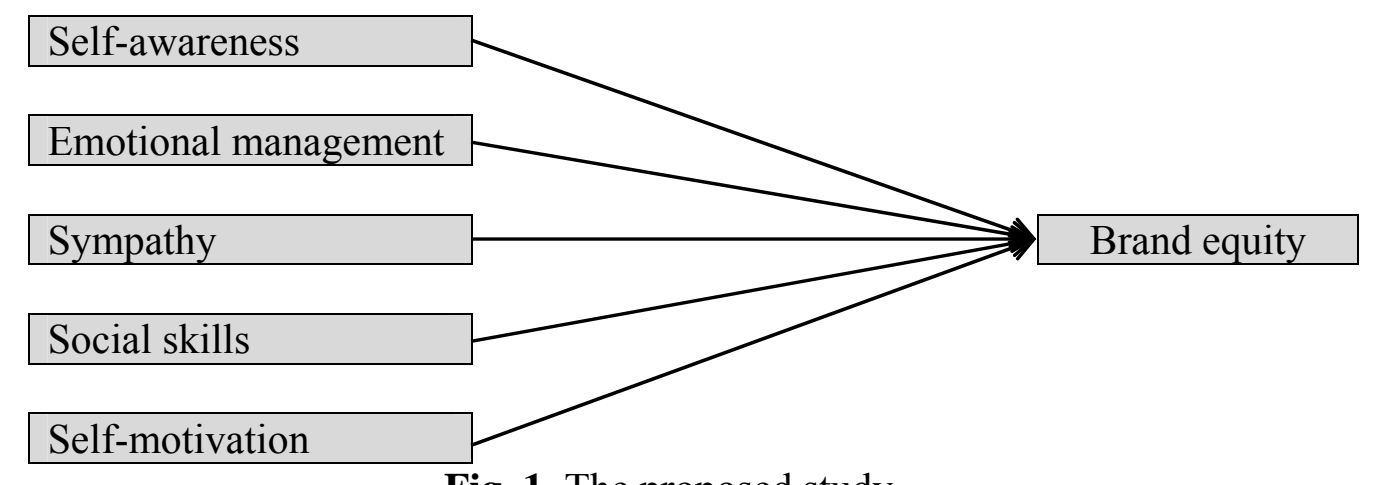

Fig. 1. The proposed study

The proposed study of this paper uses two questionnaires, one for measuring emotional intelligence, which is adopted from Goleman (2006) and the other for measuring brand equity adopted from Buil et al. (2011). The study includes all people who telecommunication services provided by Irancell in Iran. The sample size is calculated as follows,

$$
N=Z_{\alpha / 2}^{2} \frac{p \times q}{e^{2}}
$$

where $N$ is the sample size, $p=1-q$ represents the probability, $z_{\alpha / 2}$ is CDF of normal distribution and finally $\varepsilon$ is the error term. For our study we assume $p=0.5, z_{\alpha / 2}=1.96$ and $e=0.05$, the number of sample size is calculated as $N=384$. The study distributed 400 questionnaires among randomply selected people and managed to collect 384 filled ones. Cronbach alpha have been calculated for selfawareness, emotional management, sympathy, social skills and self- motivation as $0.56,0.58,0.52$, 0.42 and 0.59 , respectively.

\subsection{Personal charactersitics of the participants}

In our survey $59 \%$ of the participants were female and $41 \%$ of them were male. In addition, $78 \%$ of the people who took part in our survey were single and $22 \%$ of the remaining people were married. The average age of the participants was 26.32 and with standard deviation of 4.41 . In terms of educational background, $51 \%$ of the participants hold bachelour of science, $22 \%$ of them hold masters degree of science and $15 \%$ of them hold $\mathrm{PhD}$ degree. In our survey, the youngest person was 19 years old while the oldest one was 41 years old. 


\subsection{Basic statistics}

Table 1 demonstrates some basic statistics associated with the proposed study.

\section{Table 1}

The summary of mean and standard deviation of the questionnaires

\begin{tabular}{lccccc}
\hline & Self -awareness & emotional management & Sympathy & Social skills & Self-motivation \\
\hline Mean & 4.03 & 3.52 & 3.97 & 3.37 & 2.96 \\
Standard dev. & 0.57 & 0.82 & 0.76 & 0.91 & 0.97 \\
\hline & Brand awareness & Perception quality & Brand associate & Brand loyalty & Mean \\
\hline Mean & 3.82 & 2.89 & 3.39 & 3.14 & 3.31 \\
Standard dev. & 1.06 & 1.16 & 0.64 & 0.65 & 0.54 \\
\hline
\end{tabular}

According to the results of Table 1, self-awareness maintains the highest mean in emotional intelligence while brand awareness has the highest mean. In addition, Table 2 demonstrates the summary of correlation ratios.

\section{Table 2}

The summary of correlation ratios

\begin{tabular}{lcccccc}
\hline \multicolumn{1}{c}{ Variables } & Brand equity & Self-awareness & Management of emotions & Sympathy & Social skills & Self-motivation \\
\hline Brand equity & - & & & & & \\
Self-awareness & $0.35^{* *}$ & - & & & \\
Management of emotions & $0.34^{* *}$ & $0.24^{* *}$ & - & - & & \\
Sympathy & $-0.19^{* *}$ & $-0.12^{*}$ & $0.33^{* *}$ & -0.08 & - \\
Social skills & $0.67^{* *}$ & $0.34^{* *}$ & $0.26^{* *}$ & $0.16^{*}$ & $0.40^{* *}$ & - \\
Self-motivation & $0.55^{* *}$ & $0.45^{* *}$ & $0.14^{*}$ & & \\
\hline
\end{tabular}

* Significance level $=5 \%$

$* *$ Significance level $=1 \%$

As we can observe from the results of Table 2, there are some positive and meaningful relationships between self-awareness and brand equity $(\mathrm{r}=0.35$, Sig. $=0.01)$, between management of emotion and brand equity $(\mathrm{r}=0.34$, Sig. $=0.1)$, between social skills and brand equity $(\mathrm{r}=0.67$, Sig. $=0.01)$, between self-motivation and brand equity $(r=0.55$, Sig. $=0.01)$. In addition, there are some negative relationship between sympathy and brand equity $(\mathrm{r}=-0.19$, Sig. $=0.01)$ and between sympathy and self-awareness $(\mathrm{r}=-0.12$, Sig. $=0.01)$.

\section{The results}

In this section, we present details of our findings on examining the relationship between emotional intelligence and brand equity using structural equation modeling (SEM). Fig. 2 demonstrates the summary of SEM implementation.

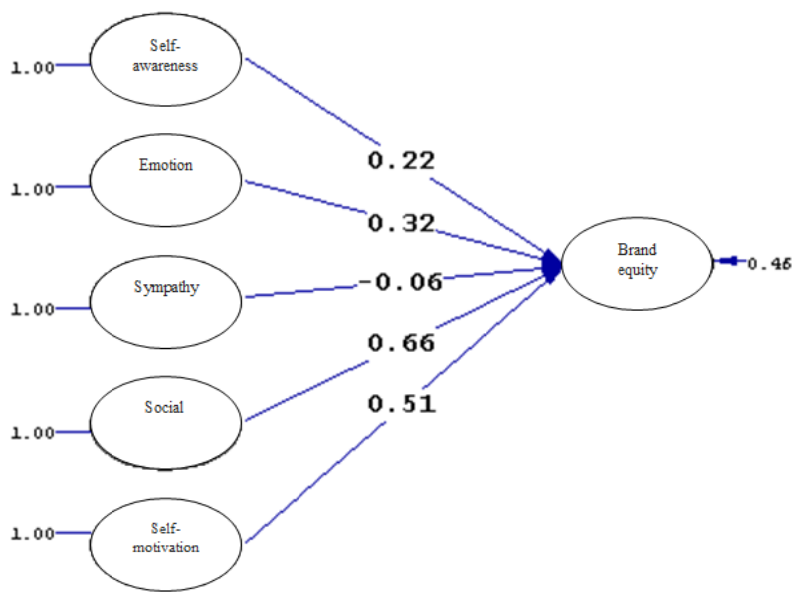

Fig. 3. The results of path analysis 
In our survey, Chi-square $/ \mathrm{df}=2.16$, which is less than desirable limit of 3 with P-value $=0.00000$ and RMSEA $=0.063$. Table 3 demonstrates the summary of other results.

\section{Table 3}

The summary of some statistical observation associated with the implementation of SEM

\begin{tabular}{ccccc}
\hline RMSEA & GFI & AGFI & CFI & NFI \\
\hline 0.063 & 0.92 & 0.91 & 0.91 & 0.86 \\
\hline
\end{tabular}

The results of Table 3 clearly show that all statistical observations are within acceptable limits. In addition, Table 4 demonstrates the summary of t-student values along with the results of testing various hypotheses. The results of Table 4 confirm four hypotheses of the survey. The highest impact belongs to the effect of social skills on brand equity followed by self-motivation.

\section{Table 4}

The summary of testing hypotheses

\begin{tabular}{lccc}
\hline Hypothesis & $\beta$ & t-value & Result \\
\hline The impact self-awareness on brand equity & 0.22 & 3.81 & Confirmed \\
The impact management of emotion on brand equity & 0.32 & 5.13 & Confirmed \\
The impact sympathy on brand equity & -0.06 & 1.28 & Not Confirmed \\
The impact social skills on brand equity & 0.66 & 9.35 & Confirmed \\
The impact self-motivation on brand equity & 0.51 & 7.85 & Confirmed \\
\hline
\end{tabular}

\section{Conclusion}

In this paper, we have presented an empirical investigation to study the impact of emotional intelligence on brand equity. The proposed model has been implemented among selected regular customers of telecommunication industry in city of Tehran, Iran. The results have confirmed that selfawareness, management of emotion, social skills and self-motivation influence on brand equity, positively. However, the survey has not found any evidence on relationship between sympathy and brand equity. It appears that social skills maintain the highest impact on brand equity.

\section{References}

Aaker, D. A., \& Joachimsthaler, E. (2003). Brand leadership (Vol. 34). FrancoAngeli.

Biedenbach, G., Bengtsson, M., \& Wincent, J. (2011). Brand equity in the professional service context: Analyzing the impact of employee role behavior and customer-employee rapport. Industrial Marketing Management, 40(7), 1093-1102

Buil, I., de Chernatony, L., \& Martínez, E. (2011). Examining the role of advertising and sales promotions in brand equity creation. Journal of Business Research.

Callarisa, L., García, L.S., Cardiff, J., \& Roshchina, A. (2012). Harnessing social media platforms to measure customer-based hotel brand equity. Tourism Management Perspectives, 4, 73-79

Goleman, D. (2006). Emotional intelligence: Why it can matter more than IQ. Random House Digital, Inc.

King, C., \& Grace, D. (2010). Building and measuring employee-based brand equity. European Journal of Marketing, 44(7/8), 938-971.

Veasna, S., Wu, W.Y., \& Huang, C.H. (2013). The impact of destination source credibility on destination satisfaction: The mediating effects of destination attachment and destination image. Tourism Management, 36, 511-526

Wood, L. (2000). Brands and brand equity: definition and management. Management decision, 38(9), 662-669. 